\title{
TWO NEW RECORDS AND ONE REDISCOVERY FOR ORCHIDACEAE OF MEXICO
}

\author{
Rodolfo Solano Gómez ${ }^{1,4}$, Rolando Jiménez Machorro ${ }^{2} \&$ Anne A. Damon ${ }^{3}$ \\ ${ }^{1}$ Instituto Politécnico Nacional, Centro Interdisciplinario de Investigación \\ para el Desarrollo Integral Regional, Unidad Oaxaca, Hornos 1003, \\ 71230 Santa Cruz Xoxocotlan, Oaxaca, México. \\ ${ }^{2}$ Herbario AMO, Montañas Calizas 490, Lomas de Chapultepec, \\ 11000 México, D.F., México. \\ ${ }^{3}$ El Colegio de la Frontera Sur Tapachula, carretera antiguo \\ aeropuerto km 2.5, 30700 Tapachula, Chiapas, México. \\ ${ }^{4}$ Corresponding author: solanogo@yahoo.com.mx
}

\begin{abstract}
Two orchid species, both previously known from Central America, are reported for the Mexican flora: Oncidium poikilostalix and Telipogon helleri. The former species was previsouly known under the name Sigmatostalix poikilostalix, and the latter as Stellilabium helleri. The rediscovery of another Mexican orchid, Plectrophora alata, is also reported, having been registered in the country 75 years ago, but not collected since then, and presumed extinct. These three species were recently discovered in the rainforest of the Tacaná volcano region, in Chiapas. Each species is described and illustrated based on the Mexican specimens and their similarities with related taxa are discussed.
\end{abstract}

Key words: Chiapas, Mexico, Oncidium poikilostalix, orchids, Plectrophora alata, Tacaná volcano, Telipogon helleri.

\section{RESUMEN}

Se reporta para la flora mexicana la presencia de dos especies de orquídeas, Oncidium poikilostalix y Telipogon helleri, ambas previamente registradas de Centroamérica. La primera se conocía ampliamente con el nombre de Sigmatostalix poikilostalix, mientras que la segunda con el de Stellilabium helleri. También se comunica el redescubrimiento 
en México de otra orquídea, Plectrophora alata, la cual había sido encontrada en el país hace 75 años y no había vuelto a ser colectada desde entonces, por lo que se suponía extinta. Estas tres plantas fueron recientemente halladas al explorar los bosques húmedos de elevaciones intermedias en la región del volcán Tacaná, en Chiapas. Cada especie se describe e ilustra a partir de especímenes mexicanos y se discuten sus similitudes con taxa relacionados.

Palabras clave: Chiapas, México, Oncidium poikilostalix, orquídeas, Plectrophora alata, Telipogon helleri, volcán Tacaná.

The Mexican region encompassing the Tacaná volcano and the Cerro Boquerón, in southeastern Chiapas, is recognized as a priority area for biodiversity conservation due to its high biological richness (Arriaga et al., 2000). However, this biodiversity is threatened by the alarming loss and transformation of their habitats due to inappropriate agricultural and livestock practices, an increasing human population, and disasters caused by natural phenomena related to climatic change (Soto-Arenas et al., 2007). Thus, there remain only small fragments of the original forest of the region, isolated from each other and immersed in a wide matrix of deforested landscapes. Despite this situation, in the Tacaná-Boquerón region it is still possible to find a high biological diversity for several groups in the forest patches and the adjacent rustic coffee farms, which are the main reservoirs for an important component of the original vegetation (Solis-Montero et al., 2005). On the other hand, in the upper parts of the Tacaná volcano there is suitable and conserved habitat that is protected within the Biosphere Reserve of the same name.

Regarding orchids, the richness in the Tacaná-Boquerón region is one of the highest for Mexico, and to date there have been 96 genera and almost 300 species reported (Cruz, 2009; Jiménez, 2009). The continuous botanical exploration in this region and search for orchids has provided plant material on which some species have recently been described as new for science (Solano, in press). There is also material belonging to orchids that were not previously known for Mexico, such as Oncidium poikilostalix (Kränzl.) M.W. Chase \& N.H. Williams and Telipogon helleri (J.T. Atwood) N.H. Williams \& Dressler, which had been reported from Central America including Guatemala, so their presence in Chiapas could be expected. On the other hand, Plectrophora alata (Rolfe) Garay, an orchid that was registered for Mexico seventy five years ago at Finca Hamburgo, a coffee farm in the region, but had not been collected again, was considered as probably extinct in the country (So- 
to-Arenas et al., 2007). Fortunately, in recent years specimens of this species were collected in localities close to Finca Hamburgo confirming that it is still present in Mexico. In this paper we report the two additional species as well as the rediscovery of P. alata for the Mexican orchid flora.

Oncidium poikilostalix (Kränzl.) M.W. Chase \& N.H. Williams, Lindleyana 21: 26. 2008. Sigmatostalix poikilostalix Kränzl., Pflanzenr. IV. 50(Heft 80): 310, f. 26D. 1922. Type: Costa Rica, without precise locality, Endres 38, 97 (syntypes W). Sigmatostalix picta sensu Atwood \& Mora de Retana (1999) not Rchb.f. 1864.

Epiphytic, caespitose, erect herb, to $11 \mathrm{~cm}$ in tall (including the inflorescence). Roots slender, cylindrical, flexuous, whitish, glabrous, $1 \mathrm{~mm}$ thick. Pseudobulb 1-leaved, light green, ellipsoid to oblong-ovoid, strongly compressed, smooth but turning rough with age, $1.5-3 \mathrm{~cm} \times 1-1.5 \mathrm{~cm}$; covered at the base by 2-4 foliose, articulated, overlapping sheaths, with a blade similar to the leaves, the sheath 1.5-2 cm long, the blade $1.5-5.5 \times 0.6-1.2 \mathrm{~cm}$. Leaf erect-arching, chartaceous, light green, narrowly elliptic, obtuse, oblique and emarginated at apex, 4.7-10 x 1-1.2 cm; the base sub-petiolate and conduplicate. Inflorescence lateral, developing from the base of the upper sheaths of the pseudobulb, 1-2 per pseudobulb and flowering season, longer than the leaf, arching, 10-13 cm long, apparently racemose but rather a panicle since it presents very short branches measuring 3 $\mathrm{mm}$ long; peduncle erect, cylindrical, as long as the leaf, $6 \mathrm{~cm}$ long, at the base with a tubular bract 3-5 $\mathrm{mm}$ long; rachis $7.5-8 \mathrm{~cm}$ long, bearing 8-12 flowers which open successively. Ovary pedicelate, arching, slightly widened towards the apex, $6 \mathrm{~mm}$ long. Flowers small, showy, not resupinate, ascending, sepals and petals greenish yellow with red spots towards the base, lip intense yellow with a large red spot at basal half, callus and claw red, column white at base, yellow at apex and with numerous red spots along the body. Sepals strongly reflexed, fleshy, acuminate, 3-veined; the dorsal one lanceolate, acute, shortly apiculate, $7 \times 1.5-2 \mathrm{~mm}$; the lateral ones narrowly ovate, slightly falcate, obtuse, shortly apiculate, 6-7 $\mathrm{x}$ 2.2-2.3 mm. Petals fleshy, oblong-elliptic, slightly falcate, acute, shortly apiculate, 3-veined, 7-8 x $1.8 \mathrm{~mm}$. Lip fleshy, flat, unguiculate; the claw semi-cylindrical, with a longitudinal keel, 2-3 mm long; blade 3-lobed, ovate-sagittate, sometimes convex; lateral lobes auricled, retrorse, $1.6 \mathrm{~mm}$ long and wide; mid-lobe broadly ovate-peltate, emarginate and minutely apiculate, $5 \times 6 \mathrm{~mm}$; callus narrowly triangular to long-acuminate, acute, $2 \mathrm{~mm}$ long. Column slender, elongated, arching, semi-cylindrical, widened at apex, wingless, with a bulbous thickening (elaiophore) at base, 6-7 mm long. Stigmatic cavity sub-apical, transversely elliptic; roste- 
llum narrowly triangular, transverse to the column axis. Pollinarium formed by two ellipsoid, yellow and longitudinally sulcate pollinia; stipe laminar, narrowly triangular, united to an ovoid viscidium. Anther apical, ovoid, triangular-rounded at apex, 2-locular, minutely papillose. Capsule ellipsoid, trigonous, $11.5 \mathrm{~mm}$ long, $6.7 \mathrm{~mm}$ wide. Seed fusiform, $384.84 \mu \mathrm{m}$ long, $58.68 \mu \mathrm{m}$ thick. (Fig. 1).

Distribution and habitat: Mexico, Guatemala (Dix \& Dix, 2000) and Costa Rica (Pupulin, 2002; 2003). In Mexico it is only known from intermediate elevations of the Tacaná volcano, Chiapas. This species grows in traditional coffee farms derived from the mountain rain forest, where it grows as an epiphyte mainly on trunks and branches of coffee trees, sometimes on coffee twigs and trunks of Inga micheliana Harms (chalum, a shade tree in coffee farms). Populations that are locally abundant between 1000 and $1716 \mathrm{~m}$ elevation. It is sympatric with orchids such as Campylocentrum micranthum (Lindl.) Rolfe, Dichaea muricatoides Hamer \& Garay, Epidendrum ramosum Jacq., Erycina crista-galli (Rchb. f.) N.H. Williams \& M.W. Chase, Maxillaria hagsateriana Soto Arenas, Notylia barkeri Lindl., Oncidium guatemalenoides M.W. Chase \& N.H. Williams, Plectrophora alata, Pleurothallis nelsonii Ames, Polystachya cerea Lindl., Prosthechea chacaoensis (Rolfe) W.E. Higgins, P. ochracea (Lind1.) W.E. Higgins, Restrepia trichoglossa F. Lehm. ex Sander, Specklinia fuegii (Rchb.f.) R. Solano \& Soto Arenas, S. glandulosa (Ames) Pridgeon \& M.W. Chase, S. lateritia (Endres \& Rchb. f.) Pridgeon \& M.W. Chase, Telipogon helleri and Trichocentrum candidum Lindl.

Specimens examined: México, Chiapas, municipio de Cacahoatán, $2.5 \mathrm{~km}$ al SW de Milán, 1716 m elev., 155'33.8" N, 927'55.9" W, 27 noviembre 2007, Jiménez 178 et al. (OAX); El Platanar, Damon s.n. (ECOSUR-Tapachula, not registered); ejido Fracción Montecristo, 1403 m elev., 155'29" N, 929'59" W, Damon s.n. (ECOSUR-Tapachula, not registered); Benito Juárez El Plan, 155'15" N, 928'55" W, 1434 m elev., Damon s.n. (ECOSUR Tapachula, not registered); municipio Tapachula, ejido Santa Rosalía, cerca de río, 1000 m elev., 15²'32" N, 92¹6'3.3" W, W. Damon s.n. (OAX, photo); ejido La Patria, 1171 m elev., 156'44" N, 92 ${ }^{\circ} 13^{\prime} 35^{\prime \prime} \mathrm{W}$, abril 2008 , Solano et al. 3093 (AMO).

Phenology: The flowering season has been registered from June to January; sometimes the same pseudobulb produces two successive inflorescences per year. Pollination has been observed both in the field and cultivation; the fruit set estimated for two populations of this species was 1.7 and 2.93\% (García-González, 2010), which were low compared with the values reported by Neiland \& Wilcock (1998) for epiphytic orchids in Mesoamerica and Caribbean (1.8-15\%). Maturation of the fruits occurs from March to June, and each capsule has 10,300 to 32,933 seeds, 
Solano Gómez, et al.: Two new records and one rediscovery for Orchidaceae of Mexico

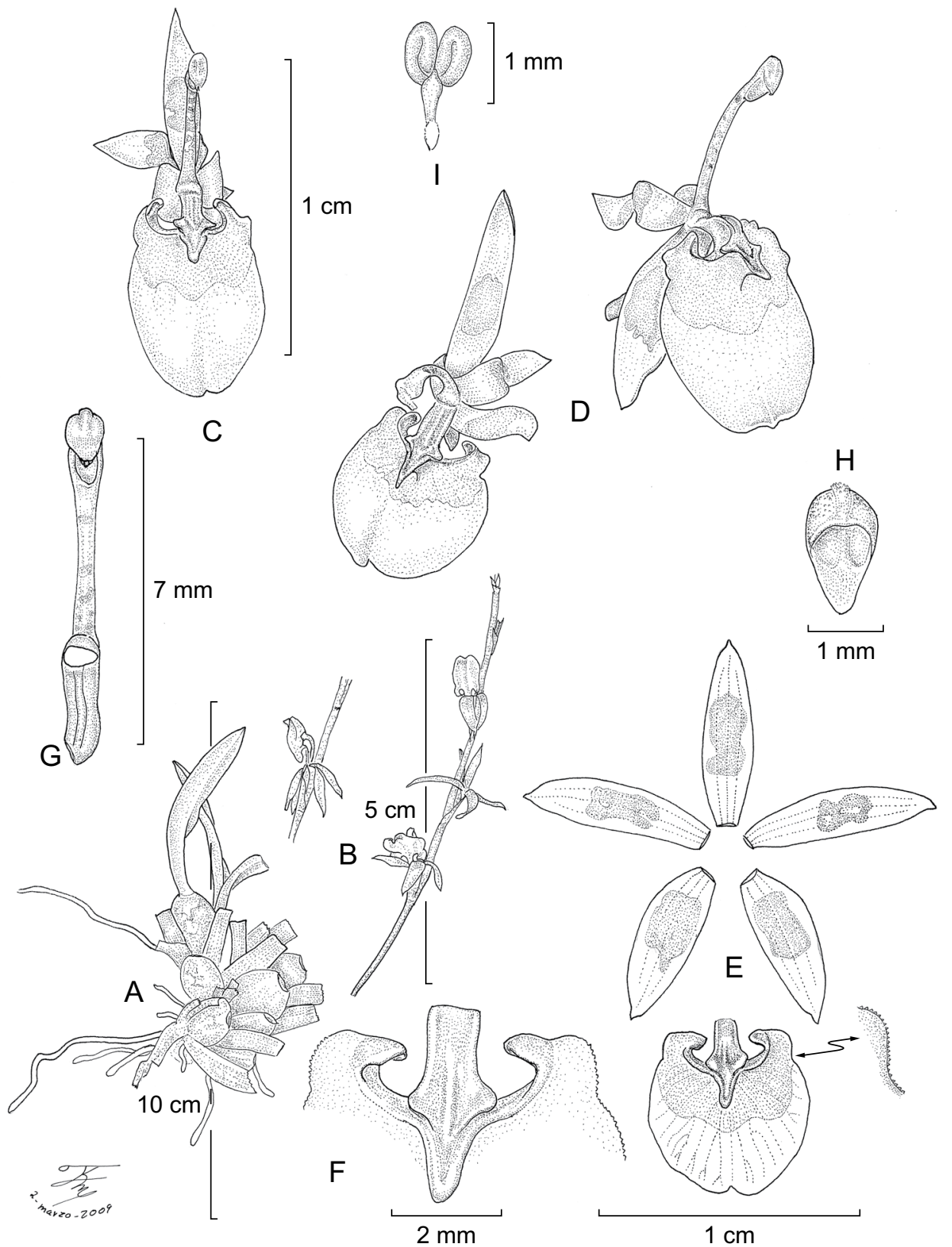

Fig. 1. Oncidium poikilostalix. A. habit; B. inflorescence segment; C. flower in frontal view; D. flowers in three quarters views; E. floral dissection; F. detail of the claw, callus, and lateral lobes of the lip; G. column; H. anther in ventral view; I. pollinarium. Drawn by R. Jiménez from Solano et al. 3093. 
with an average of 23,044. The emergence of seedlings from plants that are kept under rustic conditions after two years of cultivation has been observed (Anne Damon, personal observation).

Conservation status: This species is here reported for the first time for Mexico where it is restricted to Tacaná volcano; however, it is a coffee-farm orchid where its populations are locally abundant, and have a relatively high fruit set and seedling recruitment rates. The main risk factors for this species are the loss of its habitat, the extirpation of epiphyte biomass due to management practices in the coffee farms, and the increase of human settlements.

Comments: Recently Sigmatostalix Rchb.f. was embedded into Oncidium Sw., based on DNA sequences data (Chase et al., 2008). Oncidium poikilostalix is recognized by its oblong, compressed pseudobulbs, flowers yellow blotched with reddish-brown, and lip callus narrowly triangular. The most similar species is $\mathrm{On}$ cidium guatemalenoides (= Sigmatostalix guatemalensis Schltr.), and some authors have considered them as conspecific (Allen, 1949; Williams, 1951; Espejo-Serna \& Lopez-Ferrari, 1998; Hamer, 2001), but the latter differs by being scarcer and more robust plants, flowers lacking reddish-brown spots (at least in Mexico and Guatemala), narrower sepals and petals, longer lip claw, and the callus of the lip shorter, triangular and rounded. In Central America O. poikilostalix has been named as Sigmatostalix picta Rchb.f., but according to Pupulin (2003), this is the name for a very distinctive species restricted to Colombia and Ecuador Andes, which differs by its smaller flowers, reniform blade of the lip and callus short and rounded. Atwood \& Mora de Retana (1999) applied the name of Sigmatostalix picta for S. poikilostalix considering the flower coloration as a valuable character to distinguish it from $S$. guatemalensis, but in its northward range (Mexico and Guatemala (where the type was collected)) commonly the flowers are yellow and the reddish-brown spots are absent, while southward the flowers have the reddish-brown spots (Williams, 1951; Pupulin, 2003).

Plectrophora alata (Rolfe) Garay, Bot. Mus. Leafl. 21: 261. 1967. Trichocentrum alatum Rolfe, Bull. Misc. Inform. Kew 1898(140): 197. 1898. Type: Colombia, Millican, flowered in the Collection of Sir Trevor Lawrence, Bart. in June 1895 (K).

Epiphytic, caespitose herb, 5-6 cm tall. Roots slender, cylindrical, flexuous, whitish, glabrous, 2-3 mm thick. Pseudobulbs abbreviate, 1-leaved, ovoid, compressed, $5 \mathrm{~cm}$ long, $6 \mathrm{~mm}$ thick; covered at base by 2-3 triangular, acute, shortly apicu- 
late, conduplicate, non-foliose, carinate sheaths, disposed in fan-like arrangement, turning papyraceous with age, 9-32 $\mathrm{mm}$ long. Leaf sub-coriaceous, flatted, narrowly ovate to narrowly elliptic, acute, carinate on the external surface, $6-8 \times 1.2-1.7 \mathrm{~cm}$; attenuate towards the base into a short and conduplicate petiole. Inflorescence shorter than the leaf, from the base of the pseudobulb, covered by the upper sheath, 2-2.5 $\mathrm{cm}$ long without flowers, apparently a raceme but rather a short panicle with four branches, each branch with 2-3 successive flowers, frequently reduced to one open flower. Floral bract conduplicate, triangular, acute, $4-5.5 \mathrm{~mm}$ long. Ovary pedicelate, trigonous, shortly 3-winged, thickened towards the apex, ca. $2 \mathrm{~cm}$ long, $2.5 \mathrm{~mm}$ thick near the apex. Flowers resupinate, small, more or less showy, $1.6-1.9 \mathrm{~cm}$ tall, sepals greenish cream, petals cream, lip cream with orange and yellow stripes in the throat, column white, spur cream. Sepals fleshy, incurved; the dorsal one lanceolate to elliptic, acute, recurved along the margins, 5 to 7 -veined, $16 \times 7 \mathrm{~mm}$; the lateral ones oblique, lanceolate, acuminate, recurved at apex, 5 -veined, $19 \times 5.8 \mathrm{~mm}$, their bases extended and covering the spur. Petals incurved, obovate, sub-rounded and minutely apiculate, recurved at apex, the apical margin irregularly crenate, 5-veined, $15 \times 10 \mathrm{~mm}$. Lip fused to the column base, $16-20 \times 17-20 \mathrm{~mm}$, ovate-quadrate to subrhombic when extended, retuse, undulated along the margins, the lateral margins upright forming a trumpet which embraces the column, multi-veined; callus formed by two short and parallel keels; spur formed by the lip base, prominent, sigmoid, 40$50 \mathrm{~mm}$ long. Column short, slightly sigmoid, semi-cylindrical, widened towards the base and apex, narrowed at middle, 3-6 mm long, pubescent at base on the ventral surface. Stigmatic cavity orbicular, concave; rostellum apical, laminar, perpendicular to the column axis. Anther apical, incumbent, sub-quadrate, 2-locular. Pollinarium formed by two obovoid, sulcate pollinia; stipe narrowly triangular, united to an ovoid viscidium. Capsule not seen. (Fig. 2).

Distribution and habitat: Mexico, Guatemala (Dix \& Dix, 2000), Costa Rica (Mora de Retana \& Atwood, 1992; Pupulin, 2002), Panama (Correa et al., 2004), and Colombia. In Mexico the species is only known from intermediate elevations of the Tacaná volcano, Chiapas. It grows in coffee farms derived from montane rain forest, with "chalum" (Inga micheliana) and some remnant trees used as shade elements, between 800 and 1200 m elevation, in a semi-warm-humid climate, with an annual average temperature of approximately $19.7^{\circ} \mathrm{C}$ and annual precipitation of about $3655 \mathrm{~mm}$ (García, 1988). The plants grow on mosses in "chalum" trunks and coffee trees, forming colonies of several individuals. In one locality (La Patria) 34 individuals were counted (9 adults, 15 juveniles and 10 seedlings) growing on three host trees. 

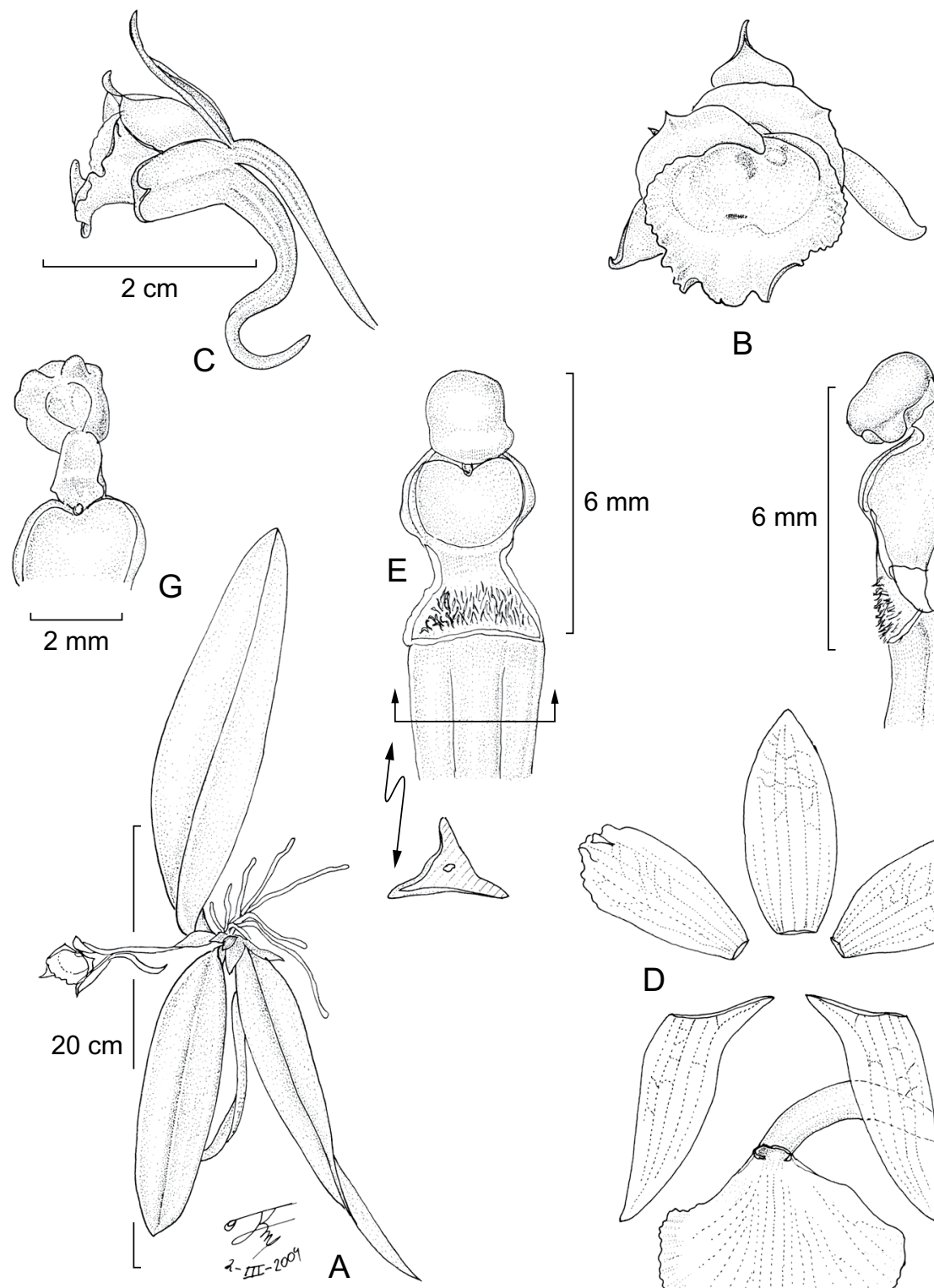

B
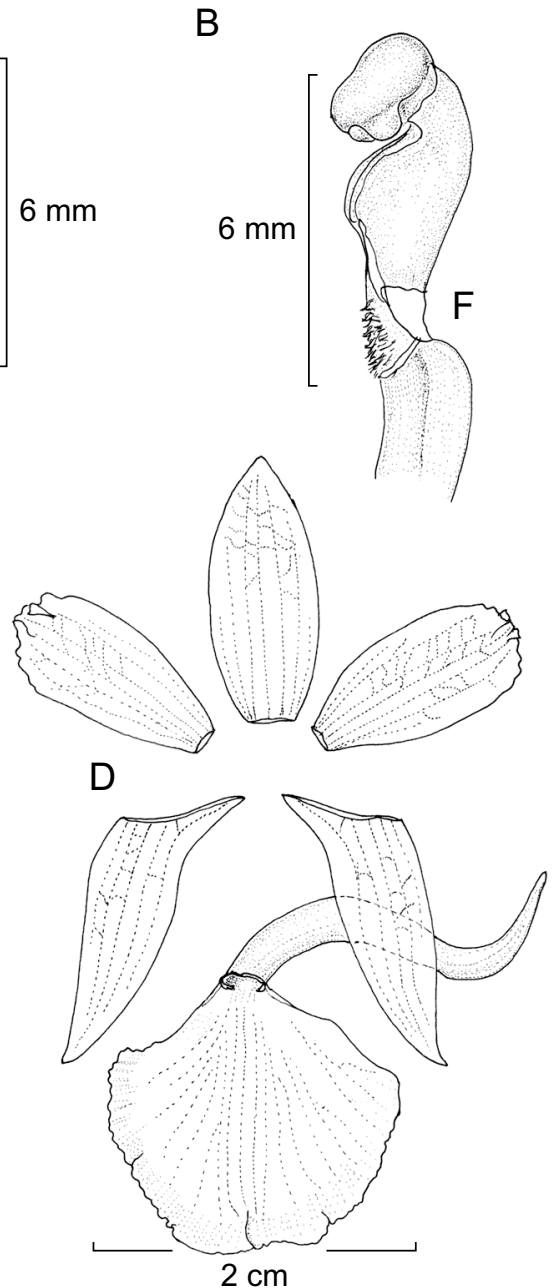

Fig. 2. Plectrophora alata. A. habit; B. flower in frontal view; C. flower in lateral view; D. floral dissection; E. column in ventral view; F. column in lateral view; G. column apex with anther removed. Drawn by R. Jiménez from Solano et al. 3091 and 3092. 
Specimens examined: México, Chiapas, municipio de Tapachula, Soconusco Mts., Finca Hamburgo, above Huixtla, on virgin forest of Río Chiripa, $900 \mathrm{~m}$ elev., 15¹0'23" N, 92¹9'31" W, 26 January 1935, Nagel sub Oestlund 4338 (AMES);

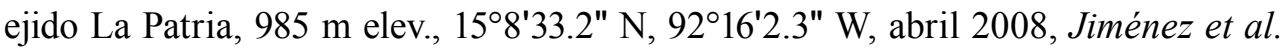
s.n. (ECOSUR-Tapachula, not registered); ejido La Patria, $1171 \mathrm{~m}$ elev., $15^{\circ} 6^{\prime} 44^{\prime \prime} \mathrm{N}$, 92 13'35" W, abril 2008, Solano et al. 3091 (OAX, in spirit); Santa Rosalía, $1000 \mathrm{~m}$ elev., 158' 32" N, 92¹6' 3.3" W, Solano et al. 3092 (AMO, hort.).

Phenology: The species flowers during the dry season, from April to June, but some specimens kept in cultivation produce flowers in October.

Conservation status: This orchid seems to be relatively common in its recently discovered localities, but in Mexico it has an restricted distribution, with populations only known from traditional coffee farms, where management practices sometimes include the extirpation of the entire epiphyte cover. The habitat of this species can also be impacted by the activities caused by ecological tourism within the highly promoted Soconusco coffee route.

Comments: This species was known for Mexico only by the specimen collected by Nagel (as Oestlund 4338, AMES) 75 years ago at Finca Hamburgo. However, there are photos taken by G. Pollard from a sterile plant collected in the same region which probably belongs this species (M. Soto Arenas, personal communication), but unfortunately no specimens were prepared from it. The species was recently considered as a probably extinct Mexican orchid (Soto Arenas et al., 2007) because no live specimens had been seen or collected in Mexico since Nagel's specimen, despite several specific searches looking for this plant in the Tacaná volcano region. This orchid is very similar in habit to Trichocentrum candidum, which is a common epiphyte in the coffee farms of the same region, and probably plants of Plectrophora alata were confused with it by botanists. However, the first differs by its very succulent leaves, flowers totally whitish, and shorter spur.

Telipogon helleri (L.O. Williams) N.H. Williams \& Dressler, Lankesteriana 5(3): 169. 2005. Stellilabium helleri L.O. Williams, Brittonia 14(4): 443-446, f. 3.1962. Type: Nicaragua, Dept. Matagalpa: On fallen tree 200 meters south of where Santa Cecilia Finca road branches off of Bavaria Finca road, near $14^{\circ} 29^{\prime} \mathrm{N}, 85^{\circ} 47^{\prime} \mathrm{W}$, alt. 1100 meters, January 1962, A.H. Heller 4093 (F, holo.; AMES, drawing from type). Dipterostele helleri (L.O. Williams) Garay \& G.A. Romero, Harvard Pap. Bot. 3(1): 57. 1998.

Small epiphytic herb, stemless, up to $12 \mathrm{~cm}$ in high including the inflorescence. Roots thick, fleshy, slightly flattened, whitish, 2-4 mm thick. Leaves up to 
3, basal, deciduous, erect, distichous, membranous (slender and translucent when dry), linear-lanceolate, acuminate, minutely dentate along the margins, carinate on the external surface, $6-10 \mathrm{~cm} \times 1-2 \mathrm{~mm}$. Inflorescence from the axils of the leaves, an erect panicle, few-flowered, 7-8.5 cm long; peduncle compressed or flattened, 3-winged, green, 0.4-0.6 mm thick, covered with 6-8 bracts which are reduced in size upwards, winged, slightly overlapping, distichous, lanceolate to ovate-lanceolate, acute, minutely dentate along the margins, green, translucent, 2.5-4 $\mathrm{mm}$ long, the wings resembling an obsolete blade; rachis strongly compressed, 3-winged, green, 0.5-0.7 mm thick. Floral bracts membranous, ovate-triangular, acute, minutely dentate along the margin, green, translucent, 0.5-1.5 mm long. Flowers minute, successively opened, 4.5-5 $\mathrm{mm}$ diameter; sepals and petals green purple, lip dark purple, columns and anther purple. Ovary slightly arcuate, cylindrical, slightly thickened upwards, greenish. Dorsal sepal concave, ovate, obtuse, sub-apiculate, glabrous, translucent, 1-veined, $1.7 \times 1.5 \mathrm{~mm}$; lateral sepals concave, obliquely ovate, obtuse, sub-apiculate, glabrous, translucent, 1-veined, 2 x 1-1.4 mm. Petals concave, oblique, ovate-elliptic, obtuse, shortly ciliate, the hairs retrorse, shortly pilose on the inner surface but more densely toward the basal third, translucent, 1-veined, 2.2-2.3 x 1-1.3 mm. Lip entire, sessile, separate from the column by a basal low sulcus, fleshythickened at the basal mid, triangular-sagittate, obtuse, shortly apiculate, glabrous on the external surface, dense and shortly pilose on the internal surface, ciliate, the hairs retrorse, $2.5-2.6 \mathrm{~mm}$ long and wide; the base with two auricles, retrorse, triangular, acute, $1.1 \mathrm{~mm}$ long, projected and embracing the column. Column sessile, very short, 3-lobed, dense and shortly pubescent, $2.5 \mathrm{~mm}$ long, $2.7 \mathrm{~mm}$ wide at the stigma level; mid-lobe upward, projected between the lateral ones and holding the anther and pollinarium, triangular, shortly pilose, the hairs simple; lateral lobes more or less rounded, densely pilose, each with a tuft of bristles, the hairs long, rigid, stelliform at the apex. Stigmatic cavity ventral, located in the middle of the three lobes, orbicular, concave; rostelum laminar, narrowly triangular. Anther apical, cordiform. Pollinarium formed by two pairs of pollinia of different size, with a Y-shaped caudicle and a hook-shaped viscidium. Capsule not seen. (Fig. 3).

Distribution and habitat: This species was previously known only from Nicaragua, where the type specimen was collected (Williams, 1962). It is possibly also present in Costa Rica and Guatemala. In Mexico the species was recently discovered from the slopes of the Tacaná volcano, in the Soconusco region of Chiapas. The species grows in coffee farms derived from montane rain forest with "chalum" (I. micheliana) and remnant trees as shade elements, at $1400 \mathrm{~m}$ elevation, in zones where the climate is semi-warm-humid, with an annual average 
Solano Gómez, et al.: Two new records and one rediscovery for Orchidaceae of Mexico

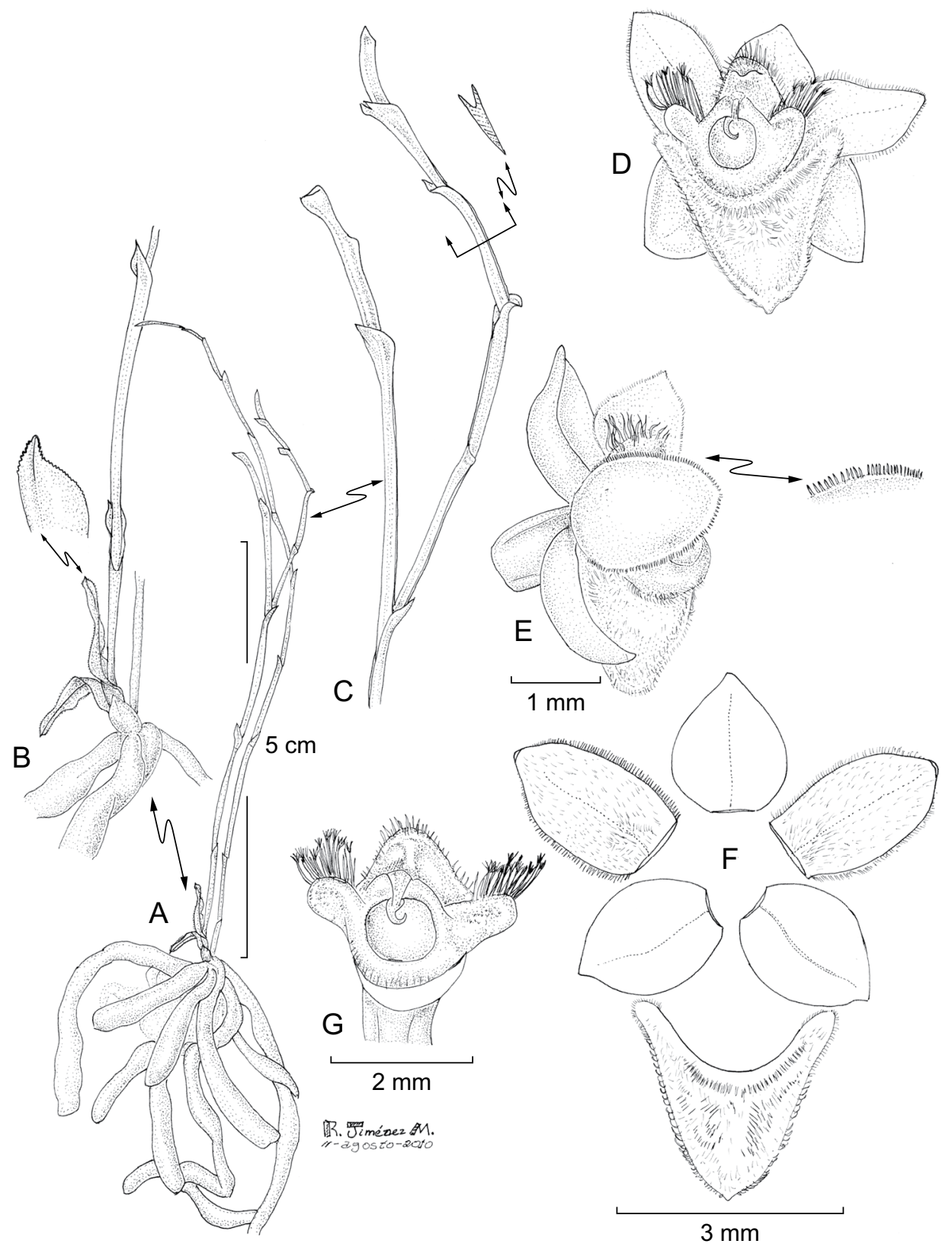

Fig. 3. Telipogon helleri. A. habit; B. leaf dry and base of the inflorescence; C. detail segment of the inflorescence showing their bracts; D. flower in frontal view; E. flower in lateral view; F. floral dissection; G. column in ventral view. Drawn by R. Jiménez from Pérez sub Solano 3050 and 3090 . 
temperature of about $20.7^{\circ} \mathrm{C}$ and annual precipitation of about $3730 \mathrm{~mm}$ (García, 1988). The plants are epiphytic on "chalum" trunks and branches but they have been found as twig epiphytes on coffee trees too.

Examined specimens: México, Chiapas, municipio de Cacahoatán, ejido Benito Juárez El Plan, 15 $5^{\prime} 15^{\prime \prime} \mathrm{N}, 92^{\circ} 8^{\prime} 55^{\prime \prime} \mathrm{W}, 1400 \mathrm{~m}$ elev., cafetal tradicional derivado de selva mediana perennifolia, colectado 28 octubre 2009, prensado 2 diciembre 2009, Pérez sub Solano 3050 (OAX); Benito Juárez El Plan, 155'15" N, 928'55" W, 1400 m elev., García sub Solano 3090 (OAX, in spirit).

Phenology: This species flowers from October to January. During 2009, in its locality 181 flowers from 51 inflorescences were counted, which were produced by 46 individual plants, of which 46 of the total flowers (25\%) were pollinated (GarcíaGonzález, unpublished data). According to Neiland \& Wilcock (1998), this value for fruit set was high for epiphyte orchids in Mesoamerica and Caribbean.

Conservation status: Unknown. Up to now the species is only known from one locality in the Tacaná volcano slopes, where the main risk factor is the transformation of its habitat due to agricultural and livestock practices, wood extraction, and the alterations provoked by activities related to an ecological tourism in the region.

Comments: The species formerly considered in Stellilabium Schltr. was embedded within Telipogon Kunth, based on DNA sequence data (Williams et al., 2005). Telipogon helleri is closely related to T. standleyi (Ames) N.H. Williams \& Dressler as was noted by Williams (1962), which is another Mexican member of the genus, but it is different by its more floriferous habit, larger flowers, obovate petals, more oblique lateral sepals, lip narrower with less divergent basal auricles, and column less pronouncedly lobed (Salazar \& Hágsater, 1992; Salazar et al., 2003); on the other hand, in Mexico T. standleyi is only known from the Sierra Madre del Sur, in Guerrero. Another similar species is the Costa Rican T. boylei (Atwood) N.H. Williams \& Dressler, but that species has larger flowers, elliptic lateral sepals and petals, lip more oblong with less projected basal auricles, and column lobes with hairs branched (Atwood, 1989; Hamer, 2001).

\section{LITERATURE CITED}

Allen, P. H. 1949. Flora of Panama part III: Orchidaceae. Ann. Missouri Bot. Gard. 36(2): 133-257.

Arriaga, L., J. M. Espinoza, C. Aguilar, E. Martínez, L. Gómez \& E. Loa (coords.). 2000. Regiones terrestres prioritarias de México. Comisión Nacional para el Conocimiento y Uso de la Biodiversidad. México, D.F. 609 pp. 
Atwood, J. T. 1989. Stellilabium boylei Atwood. Icon. Pl. Trop. 14(1): 1392.

Atwood, J. T. \& D. E. Mora de Retana. 1999. Orchidaceae: tribe Maxillarieae: subtribes Maxillariinae and Oncidiinae. Fieldiana Bot. 40: 1-182.

Chase, M. W., N. H. Williams, K. M. Neubig \& W. M. Whitten. 2008. Taxonomic transfers in Oncidiinae to accord with Genera Orchidacearum. Lindleyana 21(5): 20-31.

Correa A., M. D., C. Galdames \& M. S. de Stapf. 2004. Catálogo de las plantas vasculares de Panamá. Ed. Novo Art. Bogotá, Colombia. 599 pp.

Cruz, G. 2009. Afinidades fitogeográficas de la orquideoflora de la región Tacaná-Boquerón, Chiapas, México. Tesis de licenciatura. Instituto Tecnológico del Valle de Oaxaca. Oaxaca, Oaxaca. 129 pp.

Dix, M. A. \& M. W. Dix. 2000. Orchids of Guatemala. A revised annotated checklist. Monogr. Syst. Bot. Missouri Bot. Gard. 78: 1-61.

Espejo-Serna, A. \& A. R. López-Ferrari. 1998. Las monocotiledóneas mexicanas. Una sinopsis florística. Consejo Nacional de la Flora de México y Universidad Autónoma Metropolitana Iztapalapa. México, D.F. 115 pp.

García, E. 1988. Modificaciones al sistema de clasificación climática de Köppen (para adaptarlo a las condiciones de la República Mexicana). 4a ed. Offset Larios. México, D.F. 217 pp.

García-González, A. 2010. Reproducción de Oncidium poikilostalix (Kraenzl.) M.W. Chase \& N.H. Williams (Orchidaceae), en cafetales en el Soconusco, Chiapas, México. Tesis de maestría. El Colegio de la Frontera Sur. Tapachula, Chiapas. 149 pp.

Hamer, F. 2001. Orchidaceae. In: Stevens, W. D., C. Ulloa, A. Pool \& O. M. Montiel (eds.). Flora de Nicaragua. Angiospermas (Fabaceae-Oxalidaceae). Monogr. Syst. Bot. Missouri Bot. Gard. 85(2): 1612-1860.

Jiménez, L. 2009. Diversidad de la familia Orchidaceae en el corredor biológico TacanáBoquerón, Chiapas, México. Tesis de licenciatura. Instituto Tecnológico del Valle de Oaxaca. Oaxaca, Oaxaca. 104 pp.

Mora de Retana D. E. \& J. T. Atwood. 1992. Plectrophora alata (Rolfe) Garay. Icon. Pl. Trop. 15: pl. 1479.

Neiland, M. R. \& C. C. Wilcock. 1998. Fruit set, nectar reward and rarity in the Orchidaceae. Amer. J. Bot. 85(12): 1657-1671.

Pupulin, F. 2002. Catálogo revisado y anotado de las Orchidaceae de Costa Rica. Lankesteriana 2(2): 1-88.

Pupulin, F. 2003. A second look at the genus Sigmatostalix (Orchidaceae: Oncidiinae) in Costa Rica. Harvard Pap. Bot. 8(1): 35-59.

Salazar, G. A. \& E. Hágsater. 1992. Stellilabium standleyi, único representante mexicano de la subtribu Telipogoninae (Orchidaceae). Orquídea (México City) n.s. 12(2): 231-236.

Salazar, G. A., E. Hágsater \& M. Soto Arenas. 2003. Stellilabium standleyi (Ames) L. O. Williams. Icon. Orchid. 5-6: 696.

Solano, R. (in press). Three new species of Stelis (Orchidaceae) for Mexico. Brittonia.

Solis-Montero, L., A. Flores-Palacios \& A. Cruz-Angón. 2005. Shade coffee plantations as refuges for tropical wild orchids in central Veracruz, Mexico. Conserv. Biol. 19: 908-916. 
Soto-Arenas, M. A., R. Solano \& E. Hágsater. 2007. Risk of extinction and patterns of diversity loss in Mexican orchids. Lankesteriana 7(1-2): 114-121.

Williams, L. O. 1951. Orchidaceae of Mexico. Ceiba 2(4): 308-309.

Williams, L. O. 1962. Stelillabium helleri L.O. Wms. Tropical American Plants IV. Brittonia 14(4): 443-446.

Williams, N. H., W. M. Whitten \& R. L. Dressler. 2005. Molecular systematics of Telipogon (Orchidaceae: Oncidiinae) and its allies: nuclear and plastid DNA sequence data. Lankesteriana 5(3): 163-184.

Recibido en diciembre de 2010.

Aceptado en abril de 2011. 